УДК 347.73

DOI https: / / doi.org/10.32837 / yuv.v0i6.2047

\title{
В. Тулянцева,
}

кандидат юридичних наук,

доцент кафедри цивільного, господарського та екологічного права

Національного технічного університету «Дніпровська політехніка»

\section{ВІДПОВІДАЛЬНІСТЬ ЗА ПРАВОПОРУШЕННЯ У СФЕРІ ВИКОРИСТАННЯ ПОЗАБЮДЖЕТНИХ ЦІЛЬОВИХ ФОНДІВ}

Постановка проблеми. Наявні проблеми правового регулювання фінансових відносин зумовлені відсутністю оптимальної моделі функціонування публічних фондів, коштами яких забезпечується реалізація публічних інтересів. Соціально-економічна та політична криза, що триває в Україні, виявила неспроможність позабюджетних державних цільових фондів належним чином забезпечувати реалізацію державних зобов'язань у сфері пенсійного й соціального забезпечення, гарантування виплат за банківськими депозитними рахунками, підтримку підприємництва, охорону довкілля та інших не менш важливих сфер розвитку суспільства. Вирішення наведених та інших проблем прямо пов'язане з осмисленням закономірностей і тенденцій динаміки фінансових правовідносин щодо позабюджетних державних цільових фондів, що своїм результатом матиме забезпечення ефективності фінансово-правового регулювання діяльності таких публічних фондів.

Стан наукової розробки проблеми. Теоретичним підгрунтям наукової статті стали праці таких науковців - представників вітчизняної та зарубіжної фінансово-правової доктрини, як Є.О. Алісов, Д.О. Білінський, І.В. Біт-Шабо, Д.В. Вінницький, Л.К. Воронова, Д.О. Гетьманцев, О.О. Дмитрик, О.Б. Зайчук, Л.М. Касьяненко, Д.А. Кобильнік, А.Т. Ковальчук, А.Т. Комзюк, І.Є. Кри- ницький, О.О. Семчик, Є.М. Смичок, О.В. Солдатенко, К.О. Токарєва, Н.І. Хімічева, О.І. Худяков, В.Д. Чернадчук, Н.Я. Якимчук та інші. Отже, теоретичне підгрунтя наукової роботи становлять розробки вітчизняних i зарубіжних науковців, які висвітлюють різні аспекти функціонування фінансової системи.

Метою дослідження визначено здійснення характеристики відповідальності за правопорушення у сфері використання позабюджетних цільових фондів.

Виклад основного матеріалу. Ефективність правового регулювання суспільних відносин залежить від реалізації відповідальності зобов'язаних осіб у разі невиконання чи неналежного виконання їхніх повноважень. Найбільш поширеним різновидом правопорушень, що характеризують діяльність публічних цільових фондів, $€$ нецільове використання чи нераціональне використання належних їм фінансових ресурсів. Нормативного визначення нецільового використання коштів позабюджетних цільових фондів в України немає.

3 урахуванням положень ст. 119 Бюджетного кодексу України, якою встановлено, що нецільовим використанням бюджетних коштів $€$ «ї витрачання на цілі, що не відповідають: 1) бюджетним призначенням, встановленим законом про Державний бюджет України (рішенням про місцевий бюджет); 2) напрямам 
використання бюджетних коштів, визначеним у паспорті бюджетної програми або в порядку використання бюджетних коштів (включаючи порядок та умови надання субвенцій); 3) бюджетним асигнуванням (розпису бюджету, кошторису, плану використання бюджетних коштів)» [1].

Також відсутнім $€$ нормативне визначення категорії «посадова особа позабюджетного цільового фонду». Доцільним $є$ застосування підходу, згідно 3 яким трактування цього поняття $€$ похідним від встановленої Законом України «Про державну службу» категорії «посада» як визначеної структурою і штатним розписом первинної структурної одиниці державного органу та його апарату, на яку покладено встановлене нормативними актами коло службових повноважень [2].

Втім, відповідно до результатів судової практики вживаним $€$ розуміння посадової особи як особи, що виконує обов'язки щодо здійснення керівництва галуззю промисловості, трудовим колективом, ділянкою роботи, виробничою діяльністю окремих працівників на підприємствах, в установах чи організаціях незалежно від форм власності (організаційно-правові повноваження) та щодо управління чи розпорядження державним, колективним або приватним майном (адміністративно-господарські повноваження) (постанова Пленуму Верховного Суду України від 26 квітня 2002 р. № 5 «Про судову практику у справах про хабарництво») [3]. На підставі такого підходу керівництво позабюджетних цільових фондів також визнається посадовими особами механізму публічного управління [4, с. 43].

Відповідно до п. 17 ст. 2 Закону України «Про систему гарантування вкладів фізичних осіб» встановлюється, що уповноважена особа Фонду гарантування вкладів фізичних осіб належить до категорії спеціальних суб'єктів, наділених визначеними повноваженнями (супроводження процесу виведення банку 3 ринку фінансових послуг і його ліквідаціi), і перебуває під захистом законодавства та виконує свої функції в межах обов'язків, визначених чинним законодавством. Організація управління діяльністю Фондом гарантування вкладів фізичних осіб $€$ одним із напрямів реалізації функції держави з забезпечення стабільності банківської системи зокрема і загальної стабільності економічного розвитку країни, створюючи сприятливий інвестиційний клімат. Отже, позабюджетні цільові фонди та їх посадові особи не належать до системи органів державної влади чи місцевого самоврядування, при цьому їх функціонування спрямоване на належне виконання функцій держави, що вимагає застосування до регулювання їх діяльності відповідно до Закону України «Про запобігання корупції [5].

Посадові особи позабюджетних цільових фондів виконують під час реалізації своїх посадових обов'язків функції держави, питання про їхню відповідальність залишається невирішеним. Так, відповідно до ст. 14 Кодексу України про адміністративні правопорушення [6] посадові особи підлягають адміністративній відповідальності за адміністративні правопорушення, пов'язані з недодержанням установлених правил у сфері охорони порядку управління, державного і громадського порядку, природи, здоров'я населення та інших правил, забезпечення виконання яких входить до їхніх службових обов'язків. Тому така адміністративно-правова норма не поширюється на посадових осіб позабюджетних цільових фондів, які виконують свої обов'язки не у зв'язку з проходженням служби.

3 урахуванням зазначеного питання законодавчого закріплення категорії «посадова особа» задля підвищення ефективності відповідальності юридичних осіб публічного права, в результаті діяльності яких 
виконуються окремі функціі держави (економічна, соціальна тощо), актуалізується в сучасних умовах. Підвищенню ефективності залучення до відповідальності за вчинення порушень, пов'язаних із виконанням посадовими особами позабюджетних цільових фондів накладених на них службових повноважень, сприятиме: 1) визначення на законодавчому рівні такої групи учасників правовідносин спеціальним суб'єктом притягнення до адміністративної відповідальності за вчинення правопорушень у службовій сфері; 2) встановлення переліку підстав, що розглядаються як «нецільове використання фінансових ресурсів позабюджетних цільових фондів»; 3) активізація діяльності, спрямованої на систематизацію законодавства з питань правового регулювання діяльності позабюджетних цільових фондів взагалі і 3 питань встановлення процедури застосування заходів державного примусу до їх посадовців зокрема.

Проблема застосування заходів юридичної відповідальності до посадових осіб позабюджетних цільових фондів полягає не лише в нормативній невизначеності такої процедури, a і в тому, що недосконалою є система внутрішнього та зовнішнього фінансового контролю за їхньою діяльністю, адже, як вже зазначалось, позабюджетні цільові фонди водночас $€$ і контрольно-наглядовими фінансовими органами, і при цьому вони ж виконують функцію розпорядників фінансових ресурсів, що самостійно визначають напрями ї використання і деталізують особливості їх розподілу [7, с. 125]. Таким чином, відсутність чітко визначеного законодавством категорії «нецільове використання фінансових ресурсів позабюджетних цільових фондів» $€$ підставою для чисельних спорів, зменшення кількості яких має бути досягнуто шляхом систематизації фінансового та адміністративного законодавства в досліджуваній сфері.
Висновок. Деталізації і відповідного нормативного закріплення потребує також перелік підстав для визнання певного діяння правопорушенням у сфері використання ресурсів зазначених фондів: приміром, визнання випадком нецільового використання коштів Пенсійного фонду України використання коштів на сплату інших видів соціальних виплат (наприклад, виплат на поховання) чи виплати пенсій у необгрунтовано підвищеному розмірі тощо. Удосконалення нормативно-правової бази в аспекті юридичної відповідальності позабюджетних цільових фондів сприятиме не тільки оптимізації цієї сфери, а й позитивно вплине на становлення України як соціальної держави, яка забезпечує гідні умови життя своїм громадянам.

У науковій статті зазначено, що побудова соціальної держави передбачає створення певних умов, в межах яких забезпечуються соціально-економічні права людини й громадянина. Метою здійсненого дослідження визначено здійснення характеристики відповідальності за правопорушення у сфері використання позабюджетних ијільових фондів. Наголошено, що подальша розбудова української державності та утвердження України як соціальної держави безпосередньо пов'язується з реформуванням системи публічних фінансів країни загалом і системи позабюджетних изільових фондів зокрема. Підкреслено, що наявність фінансових ресурсів детермінує рівень ефективності реалізаціі моделі соціальної та економічно розвиненої держави. Встановлено, що нецільовим використанням бюджетних коштів $\epsilon$ ї витрачання на иілі, що не відповідають: 1) бюджетним призначенням, встановленим законом про Державний бюджет України (рішенням про місцевий бюджет); 2) напрямам використання 
бюджетних коштів, визначеним y паспорті бюджетної програми або в порядку використання бюджетних коштів (включаючи порядок та умови надання субвениій); 3) бюджетним асигнуванням (розпису бюджету, кошторису, плану використання бюджетних коштів). Визначено, що саме за рахунок акумуляціі коштів у власності держави й територіальних громад та формування публічних фондів можливе існування самої держави. Деталізації $i$ відповідного нормативного закріплення потребує також перелік підстав для визнання певного діяння правопорушенням у сфері використання ресурсів зазначених фондів: приміром, визнання випадком нецільового використання коштів Пенсійного фонду України використання коштів на сплату інших видів соиіальних виплат (наприклад, виплат на поховання) чи виплати пенсій у необгрунтовано підвищеному розмірі тощо. Удосконалення нормативно-правової бази в аспекті юридичної відповідальності позабюджетних цільових фондів сприятиме не тільки оптимізації циієї сфери, а й позитивно вплине на становлення України як соціальної держави, яка забезпечує гідні умови життя своїм громадянам.

Ключові слова: позабюджетний державний цільовий фонд, Пенсійний фонд України, публічний фонд, фінансова система, фінансово-правове регулювання, фінанси, Фонд гарантування вкладів фізичних осіб, Фонд загальнообов'язкового державного соціального страхування України на випадок безробіття, Фонд соціального страхування України, фонд.

Tulyantseva V. Responsibility for offenses in the field of use of extra-budget target funds

The scientific article states that the construction of the welfare state involves the creation of certain conditions within which the socioeconomic rights of man and citizen are ensured. The purpose of the study is to implement the characteristics of liability for offenses in the use of extra-budgetary trust funds. It is emphasized that the further development of Ukrainian statehood and the establishment of Ukraine as a welfare state is directly related to the reform of the public finance system in general and the system of extrabudgetary trust funds in particular. It is emphasized that the availability of financial resources determines the level of efficiency of the model of socially and economically developed state. It is established that the misuse of budget funds is their spending for purposes that do not meet: 1) the budget purpose established by the law on the State Budget of Ukraine (decision on the local budget); 2) the directions of use of budget funds specified in the passport of the budget program or in the order of use of budget funds (including the procedure and conditions for granting subventions); 3) budget allocations (budget schedule, budget, plan for the use of budget funds). It is determined that the existence of the state itself is possible due to the accumulation of funds owned by the state and territorial communities and the formation of public funds. The list of grounds for recognizing a certain act as an offense in the field of using the resources of these funds also needs to be detailed and appropriate: for example, recognizing the use of funds for other types of social benefits (eg funeral benefits) or pensions in unreasonably increased size, etc. Improving the regulatory framework in terms of legal liability of extrabudgetary trust funds will not only optimize this area, but also have a positive impact on the formation of Ukraine as a welfare state that provides decent living conditions for its citizens. 


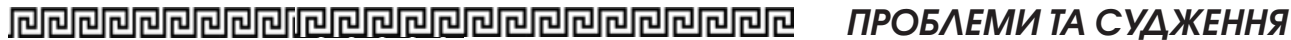

Key words: extra-budgetary state trust fund, Pension Fund of Ukraine, public fund, financial system, financial and legal regulation, finance, Deposit Guarantee Fund of individuals, Fund of compulsory state social insurance of Ukraine in case of unemployment, Social Insurance Fund of Ukraine, fund.

\section{Література}

1. Бюджетний кодекс України. Законодавство України. URL: https: / / zakon.rada.gov.ua/laws / show / 2456-17

2. Про державну службу : Закон України від 10.12.2015 p. № 889-VIII. Законодавство України. URL: https://zakon. rada.gov.ua/laws/show/889-19

3. Про судову практику у справах про хабарниитво: Постанова Пленуму Верховного Суду України від
26.04.2002 р. № 5. Законодавство України. URL: http://zakon.rada.gov.ua/ laws / show/v0005700-02

4. Іщенко О.М., Вікторчук В.М. Проблеми визначення юридичної відповідальності посадових і службових осіб Фонду гарантування вкладів фізичних осіб в Україні. Право і безпека. 2017. № 4 (67). С. 42-47.

5. Про запобігання корупиіï: Закон України від 14.10.2014 p. № 1700-VII. Відомості Верховної Ради України. 2014. № 49. Cm. 2056

6. Кодекс України про адміністративні правопорушення. Законодавство України. URL: https: / / zakon.rada.gov. ua/laws / show / 80731-10

7. Андрїв В.В., Москаленко О.В., Прилипко С.М., Ярошенко О.М. Правовідносини із загальнообов'язкового державного соціального страхування: теоретичний аспект : монографія. Харків : ФІНН, 2011. $280 \mathrm{c}$. 